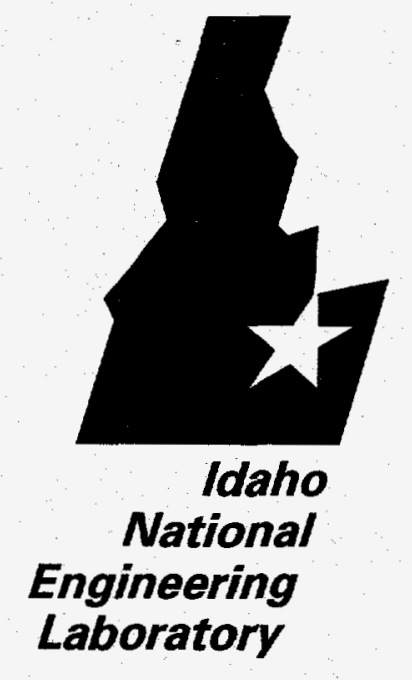

INEL-95/0171

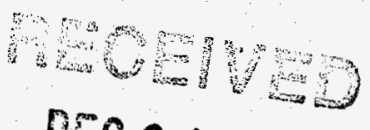

July 1995

Test Plan for a Live Drum Survey Using the Gamma-Neutron Sensor

\author{
R. J. Gehrke \\ L. G. Roybal \\ D. N. Thompson
}

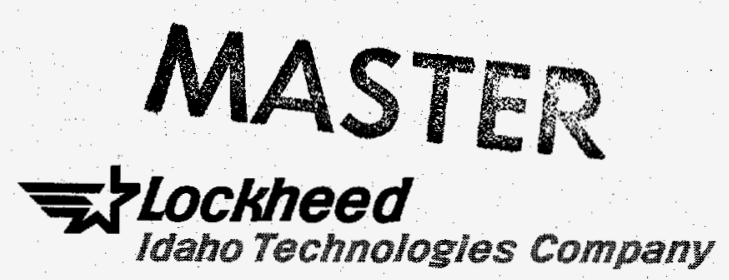




\section{DISClammer}

Portions of this document may be illegible in electronic image products. Images are produced from the best available original document. 


\title{
Test Plan for a Live Drum Survey Using the Gamma-Neutron Sensor
}

\author{
R. J. Gehrke \\ L. G. Roybal \\ D. N. Thompson
}

Published July 1995

Idaho National Engineering Laboratory

Lockheed Idaho Technologies Company

Idaho Falls, Idaho 83415

Prepared for the

U.S. Department of Energy

Assistant Secretary for Environmental Management

Under DOE Idaho Operations Office

Contract DE-AC07-94ID13223 


\section{Test Plan for a Live Drum Survey Using the Gamma-Neutron Sensor}

Prepared by

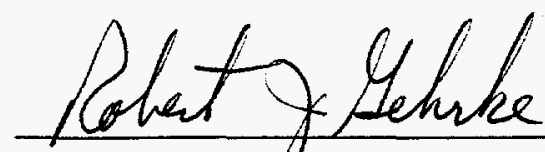

Robert J. Gehrke, Principal Investigator
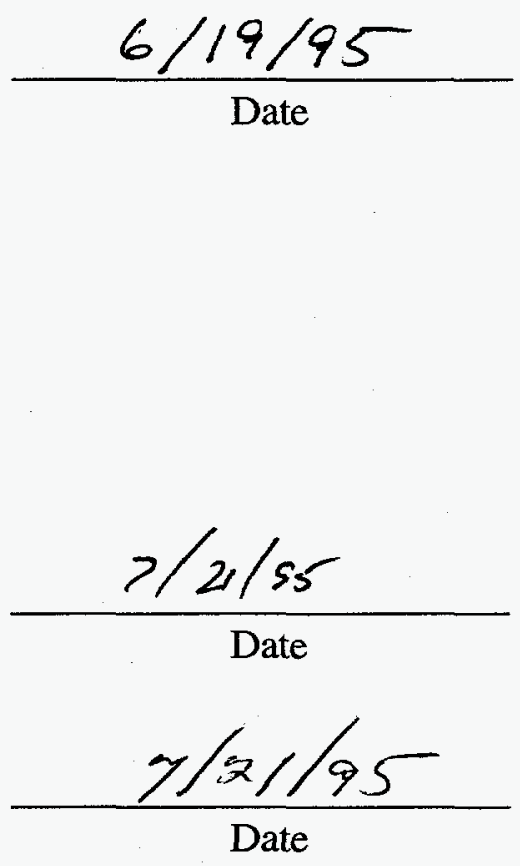

Lewis C. Rounds, Quality

Approved by

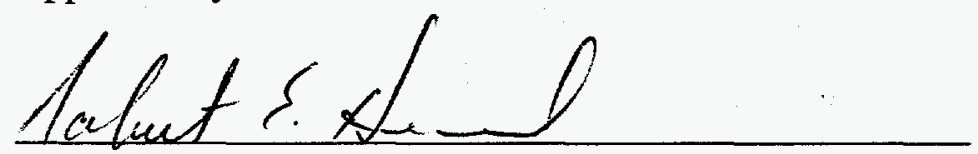

Robert E. Heard, Program Manager

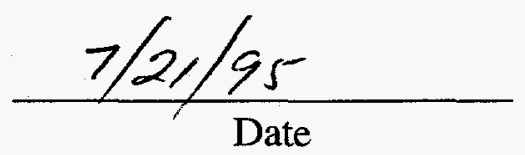




\begin{abstract}
This plan describes performance tests to be made with the Gamma/Neutron Sensor (GNS), which that was designed and built for infield assay at an excavation site. The performance tests will be performed in Building WMF-628 in the Transuranic Storage Area of the Radioactive Waste Management Complex at the Idaho National Engineering Laboratory on stored 55-gal drums of transuranic waste from the Rocky Flats Plant. The GNS is mounted on a wooden pallet that will allow horizontal and vertical scans of the stacked drums. Scanning speed and GNS sensitivity for gamma and neutron radiation fields will be estimated. Effects of temperature, electronic, and acoustic noise will be evaluated. Two- and three-dimensional plots of radiation field as a function of position will be developed from the data.
\end{abstract}

\title{
DISCLAIMER
}

This report was prepared as an account of work sponsored by an agency of the United States Government. Neither the United States Government nor any agency thereof, nor any of their employees, makes any warranty, express or implied, or assumes any legal liability or responsibility for the accuracy, completeness, or usefulness of any information, apparatus, product, or process disclosed, or represents that its use would not infringe privately owned rights. Reference herein to any specific commercial product, process, or service by trade name, trademark, manufacturer, or otherwise does not necessarily constitute or imply its endorsement, recommendation, or favoring by the United States Government or any agency thereof. The views and opinions of authors expressed herein do not necessarily state or reflect those of the United States Government or any agency thereof. 


\section{SUMMARY}

The Digface characterization concept, initially proposed at the Idaho National Engineering Laboratory (INEL) in 1992, stresses safety and efficiency of remedial field operations by promoting on-line site characterization and monitoring during retrieval. The Digface characterization system developed by the INEL is composed of geophysical, radiological, and chemical sensors controlled by an automated data acquisition and analysis system. This test plan describes the objectives and events required to perform a live radioactive drum survey using the gamma ray/neutron sensor that was developed in late FY 1994 specifically for digface applications.

Remediation of radioactive, hazardous, and mixed hazardous waste sites involves uncontrolled contact with unknown and potentially dangerous materials, initiating a complex sequence of events that includes waste assay, sorting, treating, and disposing of hazardous agents. A gross counting detector system, sensitive to gamma rays and neutrons, has been developed to rapidly scan the surface of an excavation site. High radioactive fields are indicative of buried radioactive material. The sensor system was initially procured in FY 1994 and consists of two plastic scintillation detectors that are sensitive to gamma radiation, and two ${ }^{3} \mathrm{He}$ tubes that are sensitive to neutron radiation. 


\section{CONTENTS}

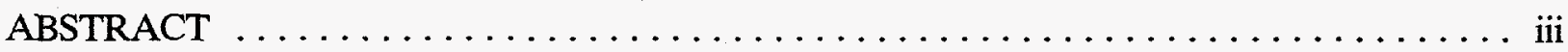

SUMMARY $\ldots \ldots \ldots \ldots \ldots \ldots \ldots \ldots \ldots \ldots \ldots \ldots \ldots \ldots \ldots \ldots \ldots \ldots$

1. INTRODUCTION $\ldots \ldots \ldots \ldots \ldots \ldots \ldots \ldots \ldots \ldots \ldots \ldots \ldots \ldots \ldots \ldots \ldots \ldots$

1.1 Technology Description and Background $\ldots \ldots \ldots \ldots \ldots \ldots \ldots \ldots \ldots$

$1.2 \quad$ Scope of Test $\ldots \ldots \ldots \ldots \ldots \ldots \ldots \ldots \ldots \ldots \ldots \ldots \ldots \ldots \ldots \ldots \ldots \ldots \ldots \ldots \ldots \ldots, 1$

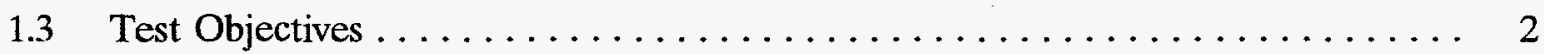

1.3.1 Data Quality Objectives $\ldots \ldots \ldots \ldots \ldots \ldots \ldots \ldots \ldots \ldots \ldots \ldots \ldots \ldots \ldots \ldots$

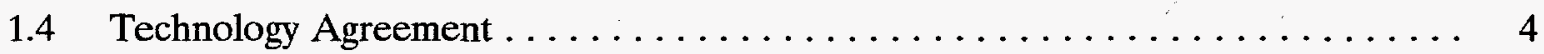

2. ORGANIZATION AND RESPONSIBILITIES $\ldots \ldots \ldots \ldots \ldots \ldots \ldots \ldots \ldots$

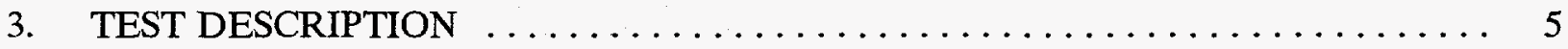

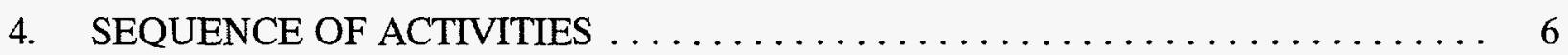

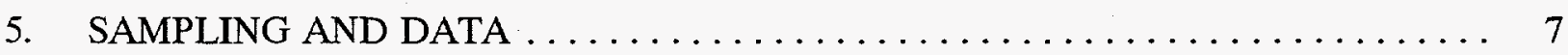

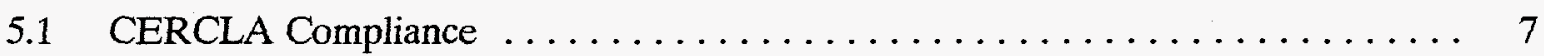

6. DOCUMENT CONTROL $\ldots \ldots \ldots \ldots \ldots \ldots \ldots \ldots \ldots \ldots \ldots \ldots \ldots \ldots \ldots$

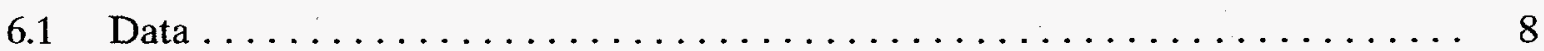

6.2 Test Plan $\ldots \ldots \ldots \ldots \ldots \ldots \ldots \ldots \ldots \ldots \ldots \ldots \ldots \ldots \ldots \ldots \ldots \ldots \ldots \ldots, 8$

6.3 Reporting and $\log$ Books $\ldots \ldots \ldots \ldots \ldots \ldots \ldots \ldots \ldots \ldots \ldots \ldots \ldots$

7. ANALYTICAL METHODS $\ldots \ldots \ldots \ldots \ldots \ldots \ldots \ldots \ldots \ldots \ldots \ldots \ldots \ldots \ldots \ldots$

8. DATA REDUCTION, VALIDATION, AND VERIFICATION $\ldots \ldots \ldots \ldots \ldots .8$

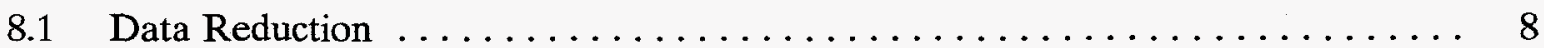

$8.2 \quad$ Data Validation $\ldots \ldots \ldots \ldots \ldots \ldots \ldots \ldots \ldots \ldots \ldots \ldots \ldots \ldots \ldots$

$8.3 \quad$ Acceptance Criteria $\ldots \ldots \ldots \ldots \ldots \ldots \ldots \ldots \ldots \ldots \ldots . . \ldots \ldots$ 


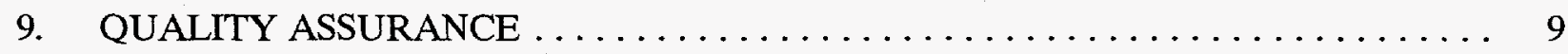

9.1 General Quality Control Methods $\ldots \ldots \ldots \ldots \ldots \ldots \ldots \ldots \ldots \ldots$

9.2 Specific Quality Control Procedures $\ldots \ldots \ldots \ldots \ldots \ldots \ldots \ldots \ldots \ldots$

10. EQUIPMENT AND INSTRUMENTS $\ldots \ldots \ldots \ldots \ldots \ldots \ldots \ldots \ldots \ldots \ldots \ldots \ldots$

11. SUPPLIES, UTILITIES, AND FACILITIES $\ldots \ldots \ldots \ldots \ldots \ldots \ldots \ldots \ldots$

12. HEALTH AND SAFETY $\ldots \ldots \ldots \ldots \ldots \ldots \ldots \ldots \ldots \ldots \ldots \ldots \ldots \ldots \ldots \ldots \ldots$

13. RESIDUALS MANAGEMENT $\ldots \ldots \ldots \ldots \ldots \ldots \ldots \ldots \ldots \ldots \ldots \ldots \ldots$

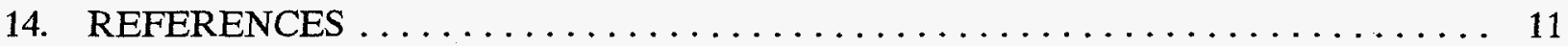

\section{FIGURES}

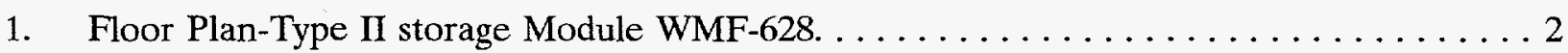

2. Schematic of GNS deployment with respect to the stacked drum arrangement at the RWMC. . . . . . . . . . . . . . . . . . . . . . . .

\section{TABLES}

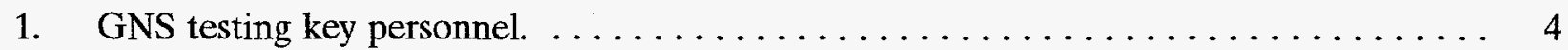

2. Operating parameters and conversion factors for the Digface characterization sensors. . 9 


\section{Test Plan for a Live Drum Survey Using the Gamma-Neutron Sensor}

\section{INTRODUCTION}

Remediation of radioactive, hazardous, and mixed hazardous waste sites involves uncontrolled contact with unknown and potentially dangerous materials, initiating a complex sequence of events that includes waste assay, sorting, treating, and disposing of hazardous and radioactive materials. These downstream activities strongly influence the speed, cost, and effectiveness of the remediation program. The Digface characterization concept, initially proposed at the Idaho National Engineering Laboratory (INEL) in 1992, stresses safety and efficiency of remedial field operations by promoting on-line site characterization and monitoring during retrieval.

The Digface characterization system developed by the INEL is composed of geophysical, radiological, and chemical sensors controlled by an automated data acquisition and analysis system. This test plan describes the objectives and events required to conduct performance tests with the gamma-neutron sensor (GNS) in Building 628 of the Transuranic Storage Area (TSA) at the Radioactive Waste Management Complex (RMWC).

\subsection{Technology Description and Background}

A gross counting detector system that is sensitive to gamma rays and neutrons has been developed to rapidly scan the surface of an excavation site. High radioactive fields are indicative of buried radioactive material. The sensor system was initially procured in FY 1994 and consists

of two plastic scintillation detectors that are sensitive to gamma radiation, and two ${ }^{3} \mathrm{He}$ tubes that are sensitive to neutron radiation.

A series of laboratory performance tests was conducted to determine basic sensor capability ${ }^{1}$. Based on the results from these tests, a number of minor modifications to the sensor were completed during the early part of FY 1995. These modifications were instituted to improve basic sensitivity and signal-to-noise level of the detectors. The purpose of this test series is to establish the sensor's capability under realistic conditions with live transuranic (TRU) waste stored in vertically stacked drums.

The GNS consists of two side-by-side plastic scintillation detectors fronting two side-by-side ${ }^{3} \mathrm{He}$ chambers in a stainless steel assembly. The sensor electronics and detectors are mounted inside an environmentally protected stainless steel enclosure, with inside access provided by a hinged door sealed with a rubber gasket.

\subsection{Scope of Test}

Performance testing of the GNS at a radioactive storage facility like WMF-628 will realistically simulate a buried waste site containing 55-gal TRU waste drums. The drums are stacked inside the new metal storage buildings in the TSA and are typically stacked five high by 
four wide. The depth of a complete stack is typically two drums deep. Figure 1 shows the floor plan of Building WMF-628 and the proposed survey site within the building.

The GNS will be mounted on a wooden pallet for deployment by a forklift truck. Horizontal and vertical movement of the sensor will be provided by the forklift with positioning performed either visually or by a laser rangefinder sensor.

\subsection{Test Objectives}

The primary objective of the Stored Waste Examination Pilot Plant (SWEPP) test series is performance testing in an actual TRU waste storage environment. The GNS was initially evaluated under laboratory conditions in FY 1994 establishing baseline capabilities of the detectors. Gamma-ray detection tests included observation of gamma-ray efficiency for given

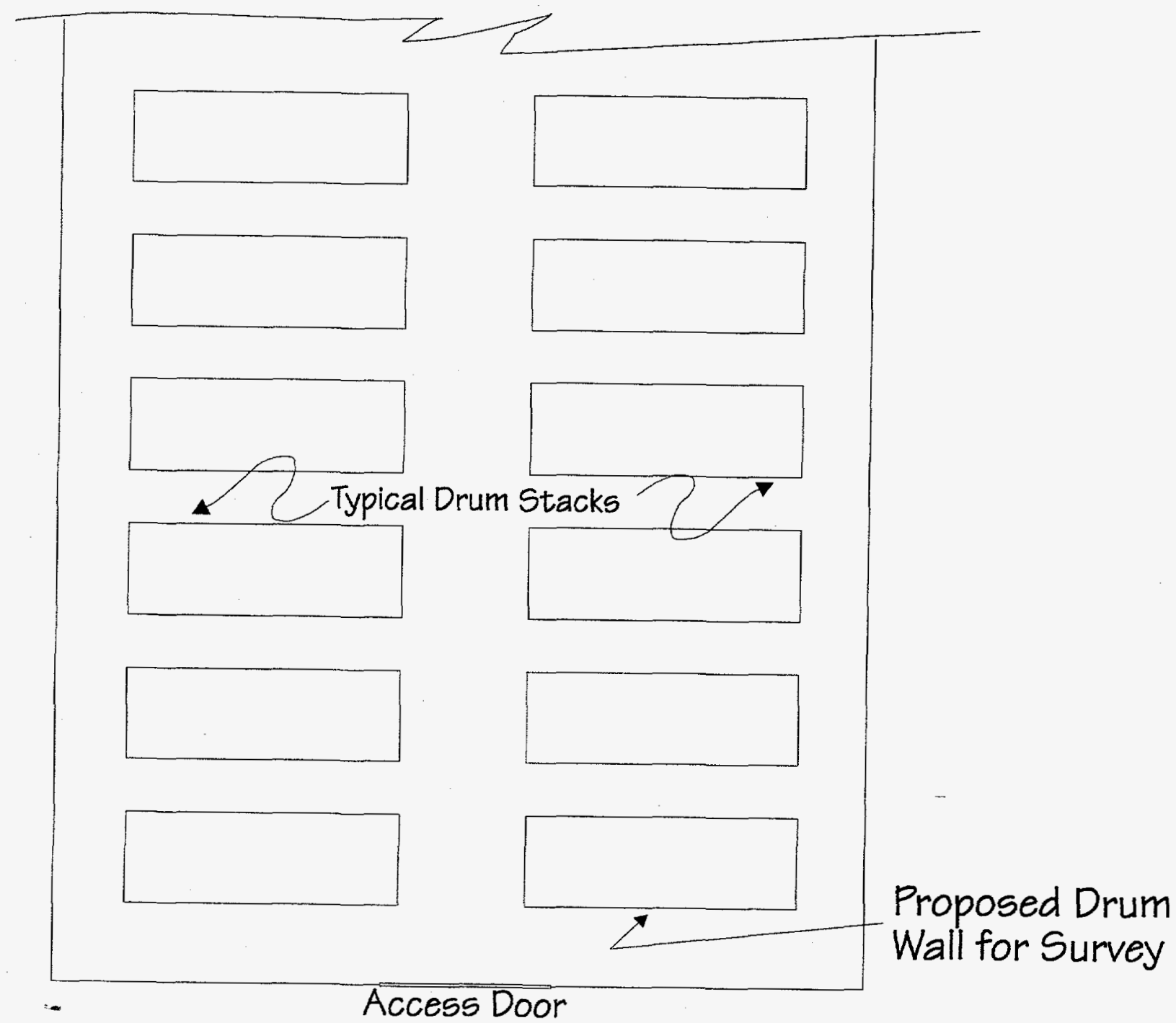

Figure 1. Floor Plan-Type II storage Module WMF-628. 
sources, count rate capability, energy range, and noise level. Neutron detection tests included determining neutron efficiency of the helium detectors for a specific source configuration, count rate capability, and threshold count rate limits. The results of the GNS laboratory tests were generally favorable, exceeding the technical specifications of the procurement in most areas, with the exception of total gamma-ray count capability. ${ }^{1}$

As a result of this initial laboratory test series, a number of in-house modifications were done to the sensor to improve its performance. A titanium window was added to the front of the detector, replacing the portion of the stainless steel front cover directly in front of the scintillation detectors to improve detector efficiency for low-energy gamma rays (e.g., ${ }^{241} \mathrm{Am}$ ). Also, a number of internal electronics modifications to the pulse processing circuitry were introduced into the detector to improve the signal-to-noise and improve overall detector sensitivity for low-energy gamma rays.

This test series is designed to demonstrate the sensor in the field environment, where the radiation fields are somewhat unknown. Specific objectives for the RMWC test series are listed below.

1. Evaluate operation of the GNS under temperature, electrical, and mechanical noise conditions representative of a field environment.

2. Locate hot drums and measure the relative strengths of the radiation fields around the stacked drums. Produce contour maps of the gamma-ray and neutron fields, using the acquisition system analysis tools.

3. Determine the effect of scan rate on the radiation field measurements.

4. Evaluate the effect of distance from the drums and sample spacing on spatial resolution of the composite data sets.

5. Evaluate the performance of the laser position sensor.

6. Estimate the sensitivity of the GMN for the detection of gamma-ray emitters such as ${ }^{241} \mathrm{Am}$. If possible, estimate the neutron sensitivity of the plastic scintillation detectors.

7. Compare measurements with drum manifest and SWEPP measurements for selected drums (This assumes that funding levels are adequate for this activity).

\subsubsection{Data Quality Objectives}

Data quality objectives consistent with performance objectives are provided below:

1. Successful operation of equipment under field conditions. If proper equipment operation is not achieved because of the field environment, we will determine the offending condition for future modifications to the system. 
2. Repeatability of the GNS detectors to within two standard deviations when counting a check source a drum under repeatable counting conditions (i.e., distance and source position).

3. Reliable data collection using surface scan rates of $30 \mathrm{~cm}$ per $10 \mathrm{~s}$. Faster scan speeds will be investigated consistent will forklift capability and safety considerations.

4. Repeatability of GNS detector counting rates to within three standard deviations when scanning stacked drums, given that the positioning of the sensor with respect to the drum is within a to-be-determined distance. This criterion will be determined at the test site.

5. Standoff positioning of the sensor to within $2 \mathrm{in.} \mathrm{of} \mathrm{the} \mathrm{desired} \mathrm{standoff} \mathrm{distance.} \mathrm{The}$ normal standoffs are 15,30 , and $60 \mathrm{~cm}$.

\subsection{Technology Agreement}

This work scope is sponsored by the Buried Waste Integrated Demonstration (BWID) as described in Technical Task Plan ID 142009.

\section{ORGANIZATION AND RESPONSIBILITIES}

Primary responsibility for this test series will belong to R. J. Gehrke, who is the principal investigator for development of the Digface characterization system GNS. Mr. Gehrke, or his designee, will have overall technical direction of this test. This test series will be performed by gamma/neutron personnel and data acquisition system personnel. The principal investigator for the data acquisition system is J. M. Svoboda. Mr. Svoboda, or his designee, will direct data field activities connected with the data acquisition system. The data acquisition system and the GNS system are under the Digface characterization system work package. The program manager for this work package is L. G. Roybal, who is responsible for overall technical coordination of the Digface project. The cost account manager for this work is J. J. Jessmore of the BWID. Brief descriptions of key technical personnel are provided in Table 1.

Table 1. GNS testing key personnel.

R. J. Gehrke'. GNS Technical Leader. Gehrke is responsible for conducting the RWMC tests and evaluating the data collected with the GNS.

J. M. Svoboda Data Acquisition System Technical Leader. Svoboda is responsible for running the data acquisition and analysis portions of this test series.

L.G. Roybal Program Manager/Technical Coordinator. Roybal is responsible for coordinating and directing technical activities concerning the Digface Characterization System Work Package. 
Live drum testing will be done at the RWMC at the new stacked drum storage facility. All RWMC training and safety requirements will be met as required by RWMC management. These requirements include Radiation Worker I training for all personnel working inside the drum storage buildings, RWMC gatehouse training for all personnel, and 24-hour Occupational Safety and Health Act (OSHA) training for all personnel.

\section{TEST DESCRIPTION}

The survey will be accomplished by attaching the GNS and the digface data acquisition system onto a specially constructed forklift pallet. The pallet will be secured to the forklift and systematically moved over one face of a drum stack while collecting measurements of the radiation fields surrounding the drums. Figure 2 shows a schematic of the GNS, data acquisition system, pallet, and forklift truck with respect to a typical drum stack in WMF-628.

The stacked drum arrangement will provide a simulated digface environment. The forklift will maneuver the gamma/neutron assembly with respect to the drums for assay. As the forklift is raised or lowered, the sensor will either (1) continuously collect radiation field measurements, or (2) stop at designated areas of the drum stack and integrate the sensor response over several

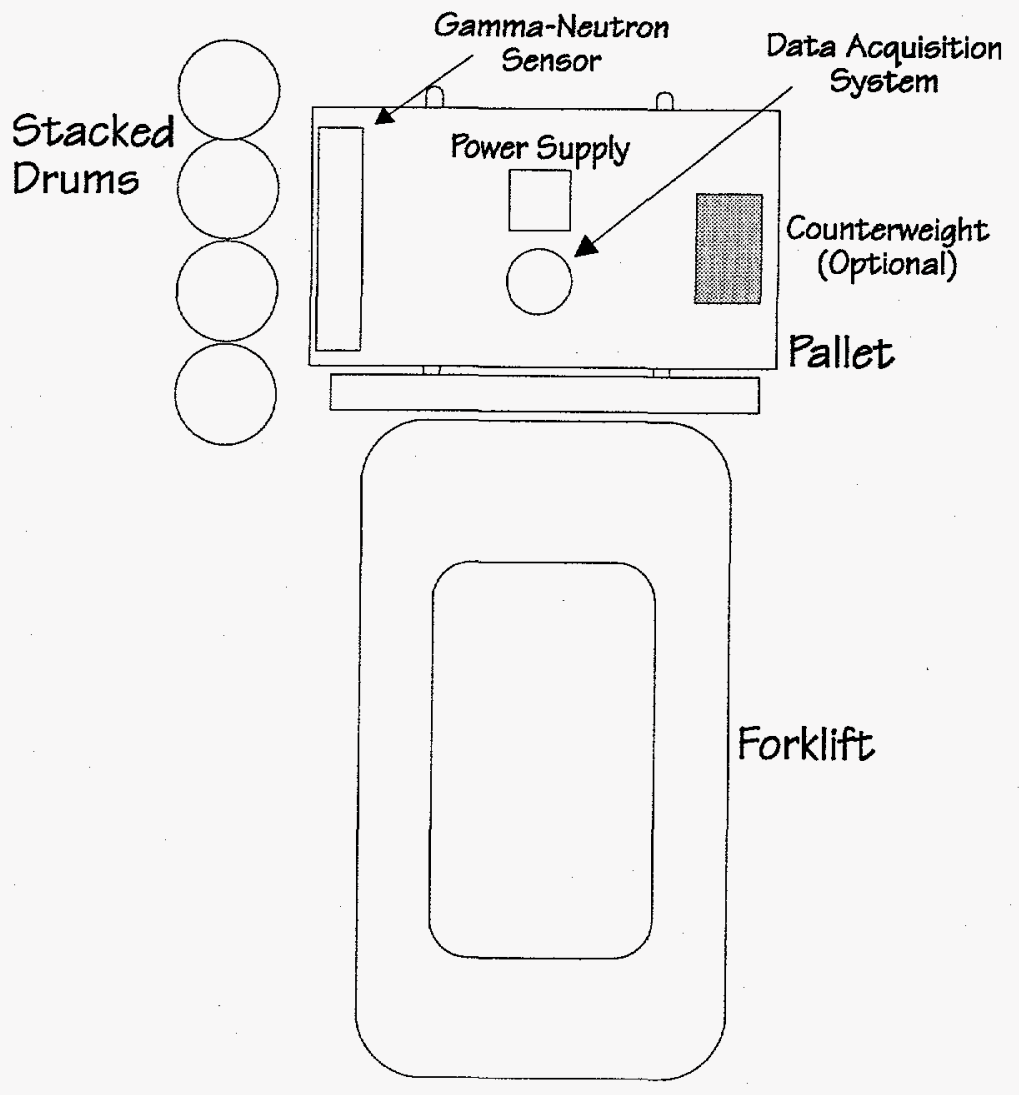

Figure 2. Schematic of GNS deployment with respect to the stacked drum arrangement at the RWMC. 
seconds to improve the sensitivity and signal-to-noise of the instrument. Measurements will be collected at distances of 15,30 , and $60 \mathrm{~cm}$ (if appropriate) standoffs between the sensor and the drum stack. At no time will the sensor assembly, pallet, forklift, or support personnel make physical contact with the stack drums.

This test is scheduled for March 31, 1995, and will be completed in one day or less. This test series will likely be completely canceled should an equipment failure occur. This is because the program costs associated with postponement of the test, and the near-term unavailability of the RWMC facility beyond this schedule window.

The conduct of the tests will generally follow that described in Section 4. A copy of the test plan will be maintained in the field. Any major deviation from this plan or test procedures will require the approval of the program manager and will be noted as a change control for the test plan. The redline method, with initials from authorizing parties, will be sufficient for change control. Logbooks will be maintained to record the test activities.

This test series provides a cost-effective method of testing the GNS, which was specifically for digface applications using live and somewhat unknown multiple gamma ray and neutron sources. If successful, this test series will provide future guidance toward developing and deploying radiological sensors at a digface with radiation hazards. Since this test is being performed with prototype equipment using a manual deployment method, estimates of full-scale operation costs and operational cycles are inappropriate at this time.

\section{SEQUENCE OF ACTIVITIES}

A Radiation Work Permit has been established with the RWMC for March 30 and 31 of 1995. Mobilization of equipment will begin on March 30, 1995. A cargo van for housing computer equipment has been reserved at the Central Facilities Area for these days. On March 30, equipment located at the Test Reactor Area (TRA) will be transported to the RWMC and checked for proper operation. Testing will begin early (8:00 a.m.) on March 31 and will be completed by the end of the day. below.

The typical startup and operating sequence for the digface data acquisition system is listed

1. Mount the sensor/pallet canister on the forklift and connect $120 \mathrm{VAC}$ power. The system will initialize and wait for commands from the SUN workstation.

2. Power up the SUN workstation (if it is not already booted) and log in using "digface" as the user id. PV-wave and the Digface application will start automatically, with the Digface main menu being displayed.

3. Press the "Alarm Setup" button and use the alarm setup window to adjust alarms and other system thresholds. Close the alarm setup window when finished.

4. Press the "Gamma Neutron" button to display the GNS acquisition screen. Set up the data file and remote $\mathrm{PC}$ executable file, along with the minimum and maximum $\mathrm{X}$ and 
$\mathrm{Y}$ distances that define the digface scan boundaries (the $\mathrm{X}$ and $\mathrm{Y}$ will be obtained from the Silicon Graphics computer if they are readily available).

5. Have the forklift operator move the sensor canister to the position at which the laser is to be zeroed.

6. Press the "Initialize Sensors" button to zero the laser.

7. When the "Start Acquisition" button is active, the system is ready to take data. As soon as the forklift is positioned and ready, press "Start Acquisition" and data acquisition will begin. The data will be displayed on the Sun workstation as they are acquired.

8. Press the "Stop Acquisition" button when the scan is completed. This will make any final updates to the data file and clear out the data file name on the screen. The system will require a new file name to be entered before starting another scan. After a file name has been entered, a new scan can be started by pressing the "Start Acquisition" button. The laser can be rezeroed at any time by moving the crane to the "zeroing" position and pressing the "Initialize Sensors" button.

9. View any of the previously acquired datasets by pressing the "Display Data" button on the main menu. The display data screen provides the operator with basic plotting and printing capabilities. The data display functions may be used concurrently with data acquisition.

10. Copy the day's datasets to floppies or $1 / 4$ in. tape at the end of each day. When the archiving is complete, exit the window system and $\log$ off the workstation.

\section{SAMPLING AND DATA}

The Digface DAS provides automated data collection and archival functions. Startup parameters are provided by the DAS operator at the SUN workstation and transmitted by RF ethernet link to the Digface sensor electronics. The data collection rate is time-based and adjustable by the DAS operator. Before data collection, system clocks will be automatically synchronized between the SUN workstation and the Digface sensor electronics. Sensor data from the Digface will be time-stamped and transmitted to the SUN workstation. The data will be archived onto disk in ASCII format, with sensor data in engineering units preceded by threedimensional position data in feet. A number of analysis functions can then be applied to the data as required including gridding, contouring, and plotting.

\subsection{CERCLA Compliance}

This is a test series of prototype equipment over an area without environmental wastes or hazards. Therefore, the nine Comprehensive Environmental Response Compensation and Liability Act (CERCLA) criteria identified in Table 2 of the BWID Demonstration Technology Test Plan Guidance ${ }^{2}$ do not specifically apply to this activity but may apply to future full-scale operations involving this equipment or derivatives of this equipment. 


\section{DOCUMENT CONTROL}

The data acquisition system has been specifically designed to automate much of the data collection and formatting. The data acquisition system acquires and converts raw sensor output (i.e. voltages) to digital values in appropriate units, places a position stamp on the data, and writes the result to permanent storage in the appropriate format for later data processing and image generation.

\subsection{Data}

The data will be incrementally archived onto floppy diskettes each day. These data will be transported and stored at the Research Office Building in Idaho Falls. Once testing is complete, a copy of all data and logbooks will be delivered to BWID upon request.

\subsection{Test Plan}

Major changes to this test plan can be made before the field work, subject to approval by the BWID project manager. These changes will be in writing and attached to the front of the original Test Plan, with the required approval signatures. A designated master copy containing the original Test Plan and all subsequent revisions will be located in the field with the test apparatus. The principal investigator, or a designated alternate, may modify the test plan to account for unanticipated conditions that might occur during the experiments. These changes will be documented by striking out and adding the appropriate text to the master copy of the Test Plan. All such changes to the Test Plan will be reported to the BWID project manager at the end of the day.

\subsection{Reporting and Log Books}

A master field logbook will be kept by the principal investigator (or designated alternate). Copies of all data and logbooks will be delivered to BWID upon request.

\section{ANALYTICAL METHODS}

Not applicable.

\section{DATA REDUCTION, VALIDATION, AND VERIFICATION}

\subsection{Data Reduction}

Most data reduction for this effort will be done automatically by the computer based data acquisition system. This involves conversion of raw sensor output (volts) to a digital value in the appropriate engineering units. Analog output ranges and conversion factors for the sensors to be used in the performance testing are listed in Table 2. 
Table 2. Operating parameters and conversion factors for the Digface characterization sensors.

\begin{tabular}{llllll}
\hline \multicolumn{1}{c}{ Sensor } & Detector type & Operating range & Output & Conversion factor $^{\mathbf{a}}$ \\
\hline Neutron detector & Helium-3 tube & -5 to +5 volts & Analog output & Maximum count rate \\
Gamma ray detector & Scintillation & -5 to +5 volts & Analog output & Maximum count rate
\end{tabular}

a. The relation of voltage to count rate is linear and determined by the maximum count rate input to the GNS by the operator.

\subsection{Data Validation}

All data for these initial checkout tests will be considered valid and used as diagnosis tools to correct deficiencies in the GNS data acquisition system or operating procedures. Data will be analyzed for proper position stamping and repeatability. Visual inspection of the data will be done by the principal investigator and/or Applied Geotechnologies personnel to ensure proper function of the sensor.

\subsection{Acceptance Criteria}

All data from a properly functioning sensor will be considered valid for purposes of these checkout tests. The data will be visually inspected by the principal investigator or designee to determine proper sensor functionality before, or during each test sequence described in the objectives section of this test plan.

\section{QUALITY ASSURANCE}

This effort will be performed in accordance with the requirements of quality level 2 as defined in the LITCO Quality Manual.

\subsection{General Quality Control Methods}

Quality control can be maintained by establishing that the experimental hardware is in proper working order before testing, and that sensors are responding properly during testing. Sensor response is addressed in Section 8 of this test plan describing data quality objectives and validation procedures. Correct hardware functionality can be ensured by performing a visual inspection of the sensor delivery system and data acquisition system at the beginning and end of each day. This inspection will concentrate on abnormal wear on mechanical components and integrity of all electrical connections.

Should an equipment malfunction, or an abnormal operating condition occur, field operations will be suspended until the problem is resolved. If the problem is considered minor, field operation may continue at the discretion of the technical field leader(s). 


\subsection{Specific Quality Control Procedures}

The Digface characterization performance testing will adopt a set of specific quality control procedures that will govern all data acquisition. The quality control procedures for Digface characterization performance testing are as follows:

Repeatability of the GNS will be monitored by duplicating data acquisition of all scans, whenever possible as discussed in Section 8.1 of this test plan. Operability and repeatability of the GNS will be checked by counting either a check source at a repeatable geometry at the start and end of each day or by counting a designated waste drum at the start and end of each day.

\section{EQUIPMENT AND INSTRUMENTS}

The bulk of equipment, instrumentation, and supplies required for this test series will be provided from within the digface characterization system concept. External equipment required for these tests includes a forklift and equipment operator, electric power from either a portable generator or a $120 \mathrm{VAC}$ power outlet, and a van or trailer for transport and to house the control station of the characterization system. Key equipment pieces are itemized below.

- $\quad$ Digface Characterization System-Self-contained data acquisition system including control software, analog-to-digital hardware, display and analysis software, radiofrequency transmission hardware, laser rangefinder, and archive capability.

- Power Supply-Power supply for the GNS. Must convert 120 -volt alternating current to 24-volt direct current.

- $\quad$ Nonconducting pallet-Specialized pallet securely holding the characterization system and GNS to the forklift.

- Forklift and Equipment Operator-Deployment vehicle for the GNS operated by an RWMC equipment operator.

- Van or Trailer-Vehicle to house the control center of the data acquisition system.

- Power Connection or Portable Generator-Supplies 120-volt alternating current to the GNS and the data acquisition system control center.

- $120 \mathrm{VAC}$ extension cords to power the GNS and the Digface characterization system in the van.

This test will occur in an unheated storage building during late March at the RWMC. Sensitivity of electronics and detectors to temperature may be a problem. The SUN workstation control center will require heated workspace for proper operation. This will be done by operating inside a heated van or trailer brought onto the site. An initial evaluation of the effects of temperature on the operation of the sensor will be made before the test series. The results of this evaluation may impact the scheduling of this test. 


\section{SUPPLIES, UTILITIES, AND FACILITIES}

Implementation of this test plan hinges upon the availability and support of personnel associated with the RWMC and the availability of an RWMC forklift and operator and a radiation control technician. Onsite requirements include the availability of 120 -volt $\mathrm{AC}$ power.

\section{HEALTH AND SAFETY}

Personnel entering the storage facility will be Radiation Worker I trained and adhere to RWMC job-specific radiological procedures and practices. Personal protective equipment will be as stated in the Radiological Work Permit, as applicable, and OSHA requirements. Personnel entering the storage facility will be OSHA trained.

The red $670 \mathrm{~nm}$ Class $3 \mathrm{~A}$ laser used to determine sensor elevation can present a blinding hazard under some circumstances. Operating procedures for the laser rangefinder have been established in accordance with LITCO procedures. The standard RWMC gatehouse and Hazards Communication training are required for all personnel on this project.

\section{RESIDUALS MANAGEMENT}

No hazardous wastes or residuals will be generated as a result of this activity.

\section{REFERENCES}

Gehrke, R. J., Lawrence, R. S., Pawelko, R. J., January 1995, Results of Performance Tests on Chemical and Radiation Measurement Systems for Use at a Dig-Face, INEL-95/0036, Lockheed Idaho Technologies Company, Idaho Falls, Idaho.

Rounds, L. C., McDonald, J. K., January 1994, Buried Waste Integrated Demonstration Technology Test Plan, EGG-WTD-9800, Rev. 1, EG\&G Idaho, Inc., Idaho Falls, Idaho. 